\title{
KADAR HAMBAT MINIMUM (KHM) DAN KADAR BUNUH MINIMUM (KBM) PADA BUNGA KENANGA (Cananga odorata (Lam.) Hook $f$. \& Thomson) TERHADAP BAKTERI Porphyromonas gingivalis SECARA IN VITRO
}

Indah Anggaraini, Sondang Pintauli, Marline Nainggolan

Program Magister Kedokteran Gigi, FKG Universitas Sumatera Utara, Medan e-mail: indahanggaraini@yahoo.com

\section{KATA KUNCI}

Porphyromonas gingivalis, minyak atsiri bunga kenanga, Kadar Hambat Minimum, Kadar Bunuh Minimum.

\section{ABSTRAK}

Pendahuluan: Gas pembentuk halitosis sebagian besar adalah gas Volatile Sulfur Compounds (VSC) yang merupakan senyawa sulfur yang mudah menguap, terbentuk dari hasil produksi aktivitas bakteri anaerob, sisa-sisa makanan, sel darah, bakteri, maupun sel epitel yang telah mati dan bereaksi dengan protein di rongga mulut yang selanjutnya akan dipecah menjadi asam amino. Terdapat tiga asam amino utama yang menghasilkan VSC, yaitu L-cysteine menghasilkan $\mathrm{H}_{2} \mathrm{~S}$, L-methionine menghasilkan $\mathrm{CH}_{3} \mathrm{SH}$, dan L-cistine menghasilkan $\left(\mathrm{CH}_{3}\right)_{2} \mathrm{~S}$. Upaya pencegahan halitosis dapat dilakukan dengan penggunaan agen antimikroba. Tujuan penelitian ini adalah untuk mengetahui efektivitas minyak atsiri bunga kenanga (Cananga odorata (Lam.) Hook. F \& Thomson) terhadap pertumbuhan bakteri Porphyromonas gingivalis. Metode: Penelitian ini merupakan penelitian eksperimen yang dilakukan di laboratorium secara in vitro. Sampel dibagi menjadi 5 kelompok perlakuan dengan minyak atsiri bunga kenanga konsentrasi 100\%; 50\%; $25 \% ; 12,5 \% ; 6,25 \%$. Kelompok kontrol positif klorheksidin glukonat $0,2 \%$ dan kontrol negatif DMSO yang diulang sebanyak 4 kali sehingga besar sampel menjadi 20 perlakuan. Hasil: Hasil penelitian menunjukkan rata-rata Kadar Hambat Minimum (KHM) terdapat pada konsentrasi $12,5 \%$ dengan diameter hambat sebesar 13,2 mm. Sedangkan Kadar Bunuh Minimum (KBM) terdapat pada konsentrasi $25 \%$ yaitu dengan diameter hambat 20,7 mm dan menunjukkan warna jernih pada design 96well plate. Simpulan: Minyak atsiri bunga kenanga memiliki aktivitas antibakteri yang mampu membunuh bakteri penyebab halitosis (Porphyromonas gingivalis) sehingga dapat dijadikan sebagai bahan antimikroba dalam mencegah pembentukan halitosis.

\section{ABSTRACT}

Introduction: Halitosis-forming gas is mostly Volatile Sulfur Compounds (VSC) which is easily evaporated, formed of the production of anaerobic bacteria activity, food debris, blood cells, bacteria, and epithelial cells that have died and react with proteins in the oral cavity which will then be broken down into amino acids. Three main amino acids produce VSC, namely L-cysteine which produce $\mathrm{H}_{2} \mathrm{~S}$, L-methionine producing $\mathrm{CH}_{3} \mathrm{SH}$, and L-cystine to produce $\left(\mathrm{CH}_{3}\right)_{2} \mathrm{~S}$. Halitosis prevention efforts can be done with the use of antimicrobial agents. The purpose of this study was to determine the effectiveness of Cananga flower essential oil (Cananga odorata (Lam.) Hook. F \& Thomson) against the growth of Porphyromonas gingivalis bacteria. Methods: This research is an experimental study conducted in a laboratory in vitro. The sample was divided into 5 treatment groups, namely the essential oil group of Cananga flower with a concentration of 100\%; 50\%; 25\%; $12.5 \%$; 
$6.25 \%$. The positive control group was $0.2 \%$ chlorhexidine gluconate and the negative control group was DMSO which was repeated 4 times thus the sample number became 20 treatments. Results: The results showed that the average Minimum Inhibitory Concentration (MIC) was at a concentration of $12.5 \%$, with an inhibitory diameter of $13.2 \mathrm{~mm}$. While the Minimum Bactericidal Concentration (MBC) was found at a concentration of $25 \%$ with an inhibitory diameter of $20.7 \mathrm{~mm}$ and showed a clear color on the 96-well plate design. Conclusion: Cananga flower essential oil has antibacterial activity that can kill the bacteria that causes halitosis (Porphyromonas gingivalis) and can be used as an antimicrobial agent in preventing the formation of halitosis.

\section{PENDAHULUAN}

Halitosis berasal dari bahasa latin, halitus (nafas) dan osis (keadaan) diartikan sebagai bau mulut yang tidak enak dan dapat muncul akibat dari penyebab fisiologis atau patologis yang dapat berasal dari oral maupun sistemik. $^{1}$

Prevalensi halitosis berkisar 20\% hingga $>50 \%$ dari populasi dunia. Prevalensi halitosis di Swiss pada usia dewasa sebesar 32\%; di Italia 53,51\%; di Arab Saudi pada usia 17-65 tahun sebesar 22,8\%; pada usia $>55$ tahun di Turki sebesar 28,3\%.4 Sedangkan di Indonesia, belum ada penelitian spesifik mengenai hal tersebut. . $^{2,3,4}$ Gas pembentuk halitosis sebagian besar adalah Volatile Sulfur Compounds (VSC). VSC merupakan senyawa sulfur yang mudah menguap, terbentuk dari hasil produksi aktivitas bakteri anaerob, sisa-sisa makanan, sel darah, bakteri, maupun sel epitel yang telah mati dan bereaksi dengan protein di rongga mulut yang selanjutnya akan dipecah menjadi asam amino. Terdapat tiga asam amino utama yang menghasilkan VSC, yaitu L-cysteine menghasilkan $\mathrm{H}_{2} \mathrm{~S}$, L-methionine menghasilkan $\mathrm{CH}_{3} \mathrm{SH}$, dan L-cistine menghasilkan $\left(\mathrm{CH}_{3}\right)_{2} \mathrm{~S}^{5,6,7}$

Sifat antimikroba dari minyak atsiri bunga kenanga telah diuji terhadap berbagai bakteri Gram positif dan Gram negatif serta jamur patogen. Menurut Anggia (2014), minyak atsiri bunga kenanga dapat digunakan sebagai antibakteri karena mengandung gugus hidroksil (-OH), karbonil dan komponen aktif berupa kariofilen. ${ }^{8,9,10}$

Eka herlina dkk. (2020) menguji aktivitas antibakteri minyak atsiri bunga kenanga dengan menggunakan metode difusi cakram agar terhadap bakteri Streptococcus aureus dan E. coli dengan konsentrasi 5\%; 2,5\%; $1,25 \%$ dan $0,5 \%$. Berdasarkan hasil penelitian didapatkan nilai zona hambat yang dihasilkan pada konsentrasi 5\% sebesar $7,32 \mathrm{~mm}$ terhadap bakteri Streptococcus aureus dan 6,86 mm terhadap bakteri E. coli. Menurut Pan dkk. (2014) pengelompokan aktivitas antibakteri digolongkan dalam tiga kategori, dimana kategori kuat adalah dengan diameter hambat $\geq 6 \mathrm{~mm} .{ }^{7}$ Berdasarkan uraian di atas, maka tujuan dari penelitian ini adalah untuk mengetahui kadar hambat minimum dan kadar bunuh minimum pada bunga 
Anggaraini: Kadar Hambat Minimum (KHM) dan Kadar Bunuh Minimum (KBM) pada...

kenanga terhadap bakteri Porphyromonas gingivalis secara in vitro.

\section{METODE}

Jenis penelitian ini adalah penelitian deskriptif yang dilakukan di laboratorium secara in vitro. Tempat dan waktu penelitian dilaksanakan pada bulan November 2019 di Laboratorium Mikrobiologi Universitas Trisakti Jakarta. Sampel pada penelitian ini adalah jumlah koloni Porphyromonas gingivalis yang diperoleh dari Laboratorium Mikrobiologi Universitas Trisakti Jakarta. Jumlah kelompok perlakuan dalam penelitian ada 5 yaitu konsentrasi 100\%; 50\%; 25\%; $12,5 \% ; 6,25 \%$. Kontrol positif klorheksidin glukonat $0,2 \%$ dan kontrol negatif DMSO yang diulang sebanyak 4 kali sehingga besar sampel menjadi 20 perlakuan. Variabel penelitian, variabel bebas adalah minyak atsiri bunga kenanga (Cannanga odorata (Lam.) Hook. F \& Thomson) dengan konsentrasi $100 \%$; 50\%; 25\%; 12,5\%; dan $6,25 \%$.

Pembuatan medium Brain Heart Infusion (BHI) dengan melakukan penimbangan BHI sebanyak 10,4gram dan dilarutkan kedalam $200 \mathrm{ml}$ aquades, kemudian diaduk sampai homogen dan dituangkan ke dalam masingmasing cawan petri. Selanjutnya cawan petri yang sudah berisi BHI dimasukkan ke dalam autoclave dan dibiarkan selama 2 jam.

Kultur bakteri Porphyromonas gingivalis dibuat dengan mengambil biakan Porphyromonas gingivalis pada cawan petri dan memasukkannya ke dalam tabung reaksi yang berisi BHI dan kemudian ke dalam anaerob jar, disimpan dalam inkubator pada suhu $37^{\circ} \mathrm{C}$ dan didiamkan selama 24 jam. Selanjutnya dilakukan pengenceran minyak atsiri bunga kenanga menjadi beberapa konsentrasi lalu dilakukan pengenceran bakteri Porphyromonas gingivalis

Uji Kadar Hambat Minimal (KHM) diawali dengan melubangi masing-masing medium agar dengan sediaan sebanyak 3 lubang. Kemudian minyak atsiri diteteskan masingmasing $50 \mathrm{ml}$ ke cawan petri yang sudah dilubangi.

Uji Kadar Bunuh Minimal (KBM) dengan metode dilusi dilakukan dengan melakukan kultur bakteri Porphyromonas gingivalis yang dimasukkan ke dalam lubang sumuran sesuai dengan design 96-well plate. Minyak atsiri dimasukkan ke dalam setiap well yang sudah diisi kultur Porphyromonas gingivalis sesuai dengan design 96-well plate sebanyak $50 \mathrm{ml}$. Masukkan blank extract (DMSO) sesuai dengan design 96-well plate, inkubasi pada suhu $37^{\circ} \mathrm{C}$ selama 24 jam dan dilakukan pengamatan.

\section{HASIL}

Hasil penelitian yang dilakukan selama 7 hari di Laboratorium mikrobiologi Universitas Trisakti Jakarta didapatkan hasil uji aktivitas antibakteri dengan menggunakan metode dilusi dan difusi yang diuji pada 5 konsentrasi, yaitu 100\%; 50\%; 25\%; 12,5\% dan 6,25\% menggunakan bakteri Porphy- 
romonas gingivalis, diperoleh hasil pada konsentrasi 6,25\%; 12,5\% masih banyak tumbuh koloni, sementara pada konsentrasi $25 \%$; $50 \%$ dan $100 \%$ tidak tumbuh koloni (Tabel 1).

Tabel 1. Hasil uji aktivitas antibakteri minyak atsiri bunga kenanga dengan metode difusi.

\begin{tabular}{|l|c|c|}
\hline \multicolumn{1}{|c|}{$\begin{array}{c}\text { Bahan } \\
\text { uji }\end{array}$} & Konsentrasi & $\begin{array}{c}\text { Pertumbuhan } \\
\text { Bakteri }\end{array}$ \\
\hline Minyak & $100 \%$ & $(-)$ \\
\cline { 2 - 3 } Atsiri & $50 \%$ & $(-)$ \\
\cline { 2 - 3 } Bunga & $25 \%$ & $(-)$ \\
\cline { 2 - 3 } Kenanga & $12,5 \%$ & $(+)$ \\
\cline { 2 - 3 } & $6,25 \%$ & $(+)$ \\
\hline
\end{tabular}

Hasil uji dalam menetapkan Kadar Hambat Minimum (KHM) dilakukan menggunakan metode difusi (Gambar 1). Rerata diameter hambat hasil uji aktivitas antibakteri minyak atsiri bunga kenanga dengan 5 konsentrasi
$6,25 \% ; 12,5 \% ; 25 \% ; \quad 50 \%$ dan $100 \%$ terhadap bakteri Porphyromonas gingivalis dapat dilihat pada Tabel 2.

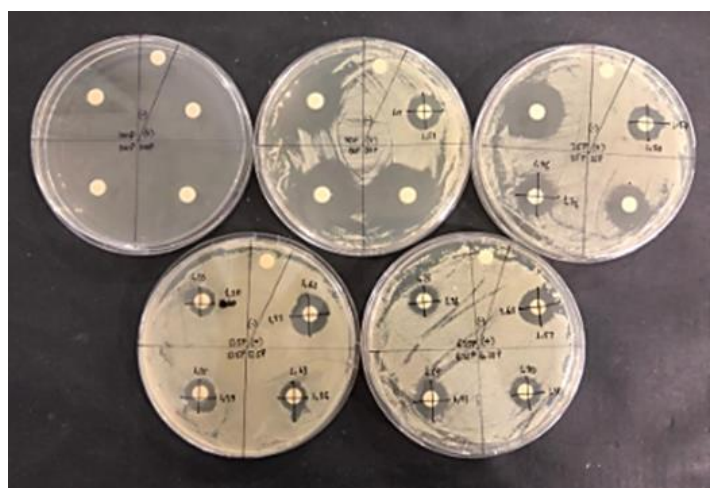

Gambar 1. Uji KHM dengan metode difusi.

Pada Gambar 1 dapat dilihat zona hambat paling kecil terdapat pada konsentrasi 6,25\% dan konsentrasi 12,5\%. Sedangkan zona hambat pada konsentrasi 100\%; 50\% dan $25 \%$ terbilang cukup besar.

Tabel 2. Rerata diameter hambat dengan metode difusi

\begin{tabular}{cccccc}
\hline No. & $\begin{array}{c}\text { Konsentrasi } \\
(\mathbf{\%})\end{array}$ & $\begin{array}{c}\text { Pengulangan I } \\
(\mathbf{m m})\end{array}$ & $\begin{array}{c}\text { Pengulangan II } \\
(\mathbf{m m})\end{array}$ & $\begin{array}{c}\text { Pengulangan III } \\
(\mathbf{m m})\end{array}$ & $\begin{array}{c}\text { Rata-rata diameter } \\
\text { hambat }(\mathbf{m m})\end{array}$ \\
\hline 1. & 100 & 38 & 38 & 38 & 38 \\
\hline 2. & 50 & 29,2 & 30,6 & 27,7 & 29,1 \\
\hline 3. & 25 & 20,2 & 17,6 & 24,4 & 20,7 \\
\hline 4. & 12,5 & 13,9 & 13,7 & 12,0 & 13,2 \\
\hline 5. & 6,25 & 13,0 & 15,3 & 12,6 & 13,6 \\
\hline 6. & Kontrol $(+)$ & 15,1 & 15,3 & 15,5 & 15,3 \\
\hline
\end{tabular}

Tabel 2 menunjukkan rata-rata diameter hambat minyak atsiri bunga kenanga terhadap bakteri Porphyromonas gingivalis. Diameter hambat pada masing-masing konsentrasi dengan 3 kali pengulangan didapatkan hasil pada konsentrasi $100 \%$ memiliki diameter hambat sebesar $38 \mathrm{~mm}$, $50 \%$ sebesar $29,1 \mathrm{~mm}, 25 \%$ sebesar $20,7 \mathrm{~mm}$,
$12,5 \%$ sebesar $13,2 \mathrm{~mm}, 6,25 \%$ sebesar $13,6 \mathrm{~mm}$ dan pada kontrol positif (klorheksidin glukonat 0,2\%) sebesar $15,3 \mathrm{~mm}$

Metode dilusi digunakan untuk menentukan KHM dan KBM dari obat antimikroba. Prinsip dari metode dilusi ini adalah menggunakan satu seri design 96-well plate 
yang diisi dengan media cair dan bakteri Porphyromonas gingivalis. KHM obat ditunjukkan dari konsentrasi terendah obat pada tabung, dengan hasil biakan yang mulai tampak jernih (tidak ada pertumbuhan mikroba).

Tabel 3. Hasil uji KBM dengan metode dilusi

\begin{tabular}{|c|c|c|c|}
\hline No & $\begin{array}{c}\text { Design } \\
\text { 96-well } \\
\text { plate }\end{array}$ & $\begin{array}{c}\text { Warna } \\
\text { larutan }\end{array}$ & \multirow{2}{*}{ KBM } \\
\hline 1. & $100 \%$ & Jernih & \\
\hline 2. & $50 \%$ & Jernih & \multirow{2}{*}{ KHM } \\
\hline 3. & $25 \%$ & Jernih & \\
\hline 4. & $12,5 \%$ & Keruh & \\
\hline 5. & $6,26 \%$ & Keruh kekuningan & \\
\hline
\end{tabular}

Pada percobaan ini diperoleh nilai KHM pada minyak atsiri bunga kenanga yaitu pada konsentrasi $12,5 \%$ dan nilai ini adalah nilai yang terbaik yang dapat menghambat pertumbuhan bakteri Porphyromonas gingivalis. Sedangkan nilai $\mathrm{KBM}$ terdapat pada konsentrasi 25\%, 50\% dan $100 \%$ ditandai dengan hasil perlakuan yang jernih (Gambar 2).

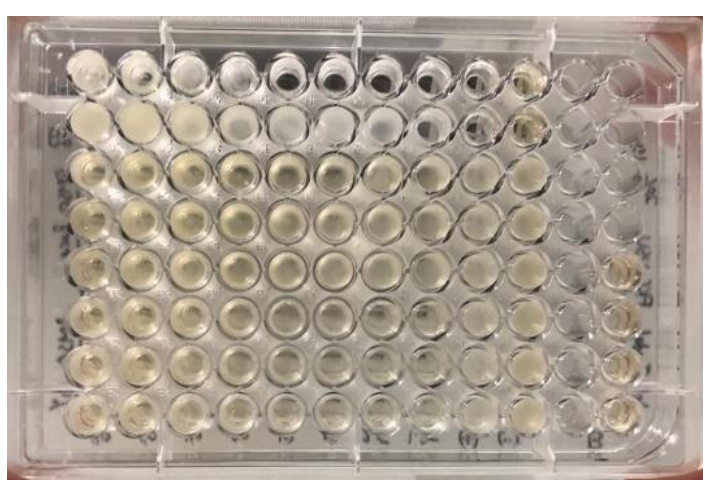

Gambar 2. Uji KBM dengan metode dilusi.

\section{PEMBAHASAN}

Penelitian ini bertujuan untuk mengetahui aktivitas antimikroba yang dimiliki oleh minyak atsiri bunga kenanga terhadap bakteri Porphyromonas gingivalis. Aktivitas antimikroba obat dimulai dengan penentuan Kadar Hambat Minimum (KHM) atau bakteriostatik dan Kadar Bunuh Minimum $(\mathrm{KBM})$ atau bakterisid dari obat secara in vitro setelah inkubasi anaerob.

Porphyromonas gingivalis merupakan bakteri Gram negatif yang merupakan penyebab utama halitosis. Bakteri ini akan memecah substrat protein menjadi rantai peptida dan asam amino yang mengandung sulfur seperti methionin, cysteine dan cystine. Bakteri Porphyromonas gingivalis merupakan bakteri anaerob yang bereaksi dengan protein-protein di dalam rongga mulut dan selanjutnya akan dipecah menjadi asam amino. Asam amino tersebut akan mengalami proses kimiawi (reduksi) yang selanjutnya akan menghasilkan Volatile Sulfur Compound (VSC), yaitu methil mercaptan $\left(\mathrm{CH}_{3} \mathrm{SH}\right)$, hidrogen sulfida $\left(\mathrm{H}_{2} \mathrm{~S}\right)$ dan dimethil sulfida $\left(\mathrm{CH}_{3}\right)_{2} \mathrm{~S}$. Sehingga dalam mengatasi halitosis harus dapat menurunkan jumlah bakteri tersebut di dalam rongga mulut. ${ }^{11}$

Zat antibakteri adalah zat yang dapat mengganggu pertumbuhan atau metabolisme bakteri. Berdasarkan aktivitasnya zat antibakteri dibedakan menjadi dua jenis, yaitu yang memiliki aktivitas bakteriostatik (menghambat pertumbuhan bakteri) dan yang 
memiliki aktivitas bakterisid. Aktivitas suatu zat antibakteri dalam menghambat atau membunuh pertumbuhan mikroorganisme tergantung pada konsentrasi dan jenis bahan antibakteri tersebut.

Hasil yang diperoleh yaitu kadar hambat minimum (KHM) pada konsentrasi 12,5\% dengan diameter hambat sebesar 13,2mm. Sedangkan kadar bunuh minimal (KBM) didapatkan pada konsentrasi $25 \%$ dengan diameter hambat sebesar $20,7 \mathrm{~mm}$. Pada penelitian ini diambil konsentrasi 25\% sebagai KBM, karena konsentrasi 25\% merupakan penetapan konsentrasi terendah dan sudah memberikan daya bunuh yang efektif terhadap pertumbuhan bakteri. Semakin tinggi konsentrasi, maka akan semakin kuat daya bunuh obat terhadap bakteri.

Hasil tersebut sesuai dengan penelitian Chungmu P (2018) yang meneliti mengenai efektivitas minyak atsiri bunga kenanga terhadap bakteri Porphyromonas gingivalis. Hasil penelitian tersebut menunjukkan minyak atsiri bunga kenanga memiliki aktivitas antibakteri dan memiliki zona hambat sebesar 12,40 $\pm 0,47 \mathrm{~mm} .{ }^{12}$

Penetapan KHM dan KBM mengacu berdasarkan klasifikasi daya hambat pertumbuhan bakteri menurut (Greenwood $1995)$ yaitu: >20mm termasuk pada kategori kuat, 16-20mm kategori sedang, 10-15mm kategori lemah, dan $<10 \mathrm{~mm}$ kategori tidak memiliki daya hambat. Sehingga KBM minyak atsiri bunga pada penelitian ini termasuk pada kategori kuat. ${ }^{13,14,15}$

Zat yang terkandung pada minyak atsiri bunga kenanga adalah alkohol (52\%-65\%) dengan ester metilbenzoat, ester linalool, dan ester terpineol, sesquiterpen (33\%-38\%), fenol, aldehida, dan aseton. Senyawa golongan sesquiterpen tersebut memiliki sifat sebagai antiinflamasi, dan antibakteri. Menurut Anggia (2014), minyak atsiri bunga kenanga juga dapat digunakan sebagai antibakteri karena mengandung gugus hidroksil (-OH) dan karbonil. Selain itu juga memiliki sifat antibakteri karena mengandung komponen aktif berupa kariofilen. 16,17 Aktivitas antibakteri yang terdapat pada minyak atsiri bunga kenanga berasal dari senyawa golongan sesquiterpen. Senyawa golongan sesquiterpen merupakan senyawa terpenoid yang dibangun oleh 3unit isopren. Senyawa sesquiterpen mempunyai efek yang cukup besar sebagai antimikroba, antifungi dan antibiotik. Senyawa $\beta$-kariofilen merupakan senyawa sesquiterpen dengan mekanisme antimikroba dengan cara merusak membran sel, sehingga terjadi kebocoran ion dari sel bakteri. Penghambatan aktivitas bakteri dapat disebabkan oleh beberapa faktor, antara lain gangguan pada senyawa penyusun dinding sel, penghambat keutuhan permeabilitas dinding sel bakteri, penghambat sintesis sel bakteri, dan penghambat sintesis asam nukleat. ${ }^{14}$ 


\section{SIMPULAN}

Berdasarkan hasil penelitian dapat disimpulkan bahwa minyak atsiri bunga kenanga memiliki aktivitas antibakteri yang mampu membunuh bakteri penyebab halitosis (Porphyromonas gingivalis) yang merupakan sumber utama pembentuk gas Volatile Sulfur Compound (VSC). Kadar hambat minimum (KHM) minyak atsiri bunga kenanga (Cananga odorata (Lam.) Hook. F \& Thomson) yaitu pada konsentrasi $12,5 \%$ dengan diameter hambat sebesar $13,2 \mathrm{~mm}$ (kategori sedang) dan kadar bunuh minimum (KBM) pada konsentrasi $25 \%$ yang ditetapkan sebagai konsentrasi terkecil yang sudah efektif dalam membunuh bakteri Porphyromonas gingivalis dengan diameter hambat sebesar 20,7mm (kategori kuat), sehingga minyak atsiri bunga kenanga dapat dijadikan sebagai bahan antimikroba dalam mencegah pembentukan halitosis.

\section{REFERENSI}

1. Wijayanti YR. Metode mengatasi bau mulut. Cakradonya Dent J.2014;6(1):630- 34.

2. Nazir M A, Aimas K, Majeed M I. The prevalence of halitosis (oral malador) and associated factors among dental students and interns. Pakistan.European Journal of Dentistry. 2019;11(4):480-81.

3. Herntan LT, Lee HL, Yin WF. Traditional uses phytochemistry, and bioactivities of cannanga odorata (ylang-ylang). Hindawi Publishing Corporation.2015;2015:13.

4. Bicak DA. A current approach to halitosis and oral malador a mini review. The Open Dentistry Journal. 2018;12: 323-25.

5. Supriatmo. Pengaruh ritma circadian terhadap produksi voliatile sulfur compounds oral.2013;20(1): 15 .
6. Alasqah M, Khan S, Elqomsan MA. Assessment of halitosis using the organoleptic method and voliatile sulfur compounds monitoring. Journal of Dental Research and Review. 2016; 3(3):95.

7. Madhushankari GS, Yamunadevi A, Selvamani M. Halitosis an overview: partclassification, etiology, and pathophysiology of halitosis. Journal of Pharmacy and Bioallied Sciences. 2015;7 (2):342.

8. Geest SD, Laleman I, Teughels W. Periodontal diseases as a source of halitosis: a review of the evidence and treatment approaches for dentist and dental hygienist. Periodontology.2016;7(1): 2013-14.

9. Kabir MH, Sarwar AF, Ahmad I. Etiological factors, diagnosis, and treatment of halitosis: a review update. J Shaheed Suhrawardy Med Call. 2013;5(2):108.

10. Codianach MM, Eduardo CK, Albuquerque R. Update of Intra extra oral causes of halitosis: A Systematic Review. OHDM. 2014;13(4):975-76.

11. Rulita M, Yuliani A, Sri H. Pengaruh jenis bunga dan waktu pemetikan terhadap sifat fisikokimia dan aktivitas antibakteri minyak atsiri bunga kenanga (cananga odorata). Teknologi dan industri pertanian Indonesia, 2016; 8 (2): 59.

12. Chungmu P, Hyunseo Y, 2018. Antimicrobial activity of essential oil against oral strain. Int J Clin Prev Dent; 14(4): 2016-15. Milah P,Bintari SH, Dewi M. Pengaruh konsentrasi antibakteri propolis terhadap pertumbuhan bakteri streptococcus pyogenes secara invitro. Life Science, 2016;5(2): 95-7.

13. Krisnawati SN, Lia UK, Rohula U. The effect of pretreatment and variation method of destilation quality of cinnamon leaf oil. Jurnal Teknologi Hasil Pertanian. 2016; 9(2)51-5.

14. Pujiarti R, Widowati T B, Kasimudjo, Sunarta S, 2015. Kualitas komposisi kimia dan aktivitas antioksidan minyak kenanga (cannanga odorata).Ilmu Kehutanan; 9(1): 4.

15. Afnidar. Fitokimia dan uji antibakteri ekstrak kalus tumbuhan serai (Wedelia biflora (L)DC.). JESBIO, 2014; 3(4): 9-16.

16. Dewa YP, Gusti GB, Wayan GG. Isolasi dan identifikasi senyawa minyak atsiri dari tumbuhan sembukan (paederia foetida 1) dengan metode kromatografi gasspektroskopi massa (GC-MS). Jurnal Kimia.2016;10(1): 149-54. 
17. Aisyah MP, Anasthasis OM, Silvia A, Siti M, Putri AR. Analisis kualitatif kandungan bunga kenanga (Cananga odorata) secara fitokimia dengan menggunakan pelarut etanol. Reseach and Education Chemistry (JREC), 2020; 2(1): 43-7. 